\title{
CULTURAL NETWORKS ITALIART AND RUART: INTERNATIONAL ART PARTNERSHIP
}

\section{E. Van Holsten, A. Koroleva, A. Nikiforova}

Emanuel Van Holsten - Master in Visual Communication Technique (DWA Dusseldorf, Germany); Master Visual Arts and Applications (Kholn, Germany), Executive Director and Art Curator of ITALIART by ARS NOVA Russia / Italian Division. http://www.vanholsten.com/ 20131, Milan, P. le Udine, 6. E-mail: evh@italiart.ru

Alina A. Koroleva - Ph.D. in Culture studies, Associate Professor, Department of advertising and public relations, MGIMO University. 119454, Moscow, prospect Vernadskogo, 76; Vernadsky State Geologival Museum of the Russian Academy of Science. 125009, Moscow, Mokhovaya str., 11, p. 11. E-mail: a.koroleva@inno.mgimo.ru

Anastasia N. Nikiforova - Bachelor of Public Relations and Advertising, MGIMO University; Student of the MA programme "Teaching interpreters for international organizations", MGIMO University. 119454, Moscow, prospect Vernadskogo, 76. E-mail: murchiforova@gmail.com

Van Holsten E., Koroleva A., Nikiforova A. 2020. Cultural Networks Italiart and Ruart: International Art Partnership. Concept: Philosophy, Religion, Culture. Vol. 4. № 1(13). P. 181-185. https://doi.org/0.24833/2541-8831-2020-1-13-181-185

Received: 26.01.2020. Accepted: 03.03.2020.

Conflicts of interest. The authors declare absence of conflicts of interest.
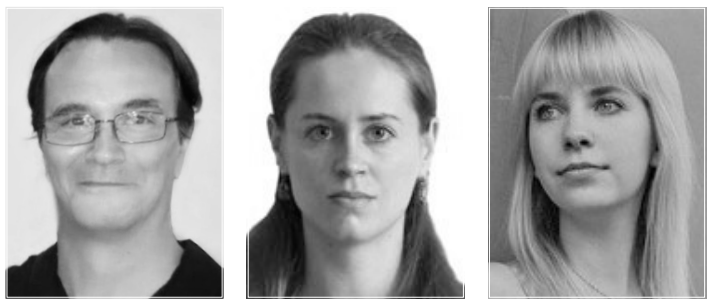

Abstract. The networking format becomes the most widespread form of international cooperation in the field of culture at the present stage. First, it attracts subjects of the international market of culture and art by reducing costs and the price of implementing projects. Both previously existing organizations and new partner projects have adopted this format and transformed themselves into networks, building their structure on the principle of horizontal communications. Along with representatives of state structures and international organizations, there are networks initiated by independentexperts interested in the development of international private partnership. In 2020, the 3rd panoramic exhibition of contemporary Italian art «Italiartkremlin» will be held in the State Museum of Modern Art of the Russian Academy of Sciences. Apart from the worksof Italian masters, the exhibition will present the works of Russian artists, winners of the annual contest «My ltaly» and "Italy through the eyes of Russian artists». "Italiartkremlin» is one of the projects of the ITALIART cultural network that unites the efforts of representatives of the Italian art market, as well as amateurs and collectors of contemporary Italian art in order to promote it in Russia and Europe. The partner network RUART specializes in the promotion of Russian art in the world, and especially in Northern Europe, through the organization of thematic art events, including art exhibitions, contests and seminars. The idea of sharing a single exhibition space of works of art from different countries allows to compare and see the difference between national schools and modern art concepts.

Keywords: cultural networks, intercultural communication, contemporary art, exhibition, Italian art, marketing in the cultural sphere. 
C ultural networks become the main resource for the international partnership in the field of culture, because the multilateral cooperation is gradually replacing the bilateral cultural relations. Although the network society is forming on global level, the level of its development varies in different countries. The only way to success within such terms is to connect the local projects in this field using cultural networking.

Globalization can be viewed both positively and negatively. On the positive side, it has enriched modern society economically, scientifically, and culturally. Once isolated communities, cultures, and individuals nowadays constantly and inevitably keep in touch with each other. However, culture remains an integral part of identity, while modern local cultures increasingly depend on growing migration processes. With information technologies developing past sociocultural boundaries in modern society are transformed, while identification boundaries become more flexible and mobile. National and non-governmental organizations, social movements, tourism, migration, and interethnic and intercultural contacts result in the emergence of new translocal and transsocietal identities [Brun, Benito, Canut, 2008].

Regarding the goals that nations create diplomatic networks around in their cultural activities, it can be said that the major one is to promote national interests by spreading the nation's culture and, therefore, values abroad. This is often done through the spread of the country's language and a facilitation of access of foreigners to its education.

Regarding the issues and threats that nations create diplomatic networks around in their humanitarian activities, it can be said that they come from both conflicts and natural disasters. The major goals nations pursue are to assist people in need and, in the first case, to curb the scope of the conflict, while, in the second, to address the impact of natural disasters.

As for the major stakeholders in diplomatic networks, we have observed that, in case of cultural activities, nations tend to initiate networks or boost their activities through creating governmental bodies or financing nationbased NGOs, whereas, in case of humanitarian activities, nations tend to join their efforts with those of universal or regional IGOs or big international NGOs [Martínez, 2016: 167177].

Finally, one more trend can be clearly observed, in their cultural and humanitarian activities, nations tend to interact more with the regions they have historical connections with and, therefore, greater influence in.

With the development of information and communication technology, culture reached the earlier non-existent cyberspace, which is conveniently called virtual. Here, we refer to multidimensional worlds created by social groups in the global space and to the culture of modern mass media or mass audiovisual culture, which is defined by M. Castells as a culture of real virtuality [Castells, 2001: 121].

At present, cultural cooperation is of network nature. Network operational format opened up new horizons for cultural institutions. The first modern international and European networks were created in the 1970 s1980s. They unite regional, national, and local participants. Networks were formed owing to cooperation of different countries, nongovernmental organizations, and cultural associations [Koroleva, 2015: 142].

In the 1990s, the idea of networking was developed first in the United States and later in Europe. The new format was becoming more popular in culture among content creators primarily for economic reasons. They created not only new cultural networks. Some existing institutions specializing in this area seized new opportunities offered by networks, primarily the Internet.

At present, the term "network" is interpreted in two ways. In a broad sense, this term also covers network formats that existed in the past. In a narrow sense, this term denotes only networks that provide for new operational formats and methods. More often than not, these networks have no hierarchy or main core, with prevailing horizontal communications. But above all, they are international [Bosselman, 2006: 3]. Networks develop by adding new clusters and eliminating those that do not serve the purpose. Cultural networks make it possible to create a market for cultural products. In addition, they take into account specific features of cultural market- 
ing, which is characterized by a mission, social targeting, focusing on educated customers, creativity, and innovations.

Relocation of marketing communication to the Internet and creation of specialized networks change the nature of relations from incidental and local partnerships to systematic and transnational ones. In addition, multilateral cultural cooperation replaces bilateral relations.

The establishment of the European Union resulted in a reduction in the bilateral cultural relations model on the European continent. Europeans find it hard to accept the new status quo, because «friend - foe» stereotypes are pretty much alive. No matter how many statements are made by the European Union, residents of other states are perceived as foreigners. The cultural cooperation paradigm can be articulated on the basis of environmentalists slogan: «Think globally, act locally». Networks take care of geographical and thematic diversity of their participating cultural partners. Even though they clash with local missions, the only way to success is through internationalization: local projects are united directly and form a global network [Koroleva, 2015: 145].

Although we are living in the «Age of Globalization and media sharing» ${ }^{1}$ more and more often this concept assumes a predominantly commercial value more than cultural connotation. There are many indications, even at the international level, that the concept expressed above is masterfully applied. "In the name of philanthropy» and "for fabulous relations between Nations» these events are nothing but a «fair of vanities» where the concept expressed above is masterfully applied. Far from demonizing the commercial logic that governs the sharing of cultural values and union between countries and communities, sharing has its costs and these costs have to be covered by sponsors or by the sale of products.

This premise was the starting point to be analyzed in 2015 when the ITALIART net- work $^{2}$ was launched in Russia; an ambitious project aimed at making the Russian people know Italian contemporary art.

The main intent was to focus on the most contemporary artists, thus without necessarily considering those Italian excellences already well known in the world; exhibiting those artists without a «big name» but who were following a path of research and study aimed to create the Great Art.

Foundations have been laid for a "real cultural exchange", which was not just a display of great works and big names, but also the artistic soul of a great country. However, without those Big Names surely neither the sponsors nor the philanthropists would have given their support, so the project had to be totally financed by the artists themselves through the participation fees to the exhibitions.

The project resulted in a sincere and spontaneous sharing which, however, was not bilateral. For that reason RUART ${ }^{3}$ has been created, the ITALIART twin project conceived with the aim of spreading Russian art on the Italian and European territory. Building on previous experiences, the growth and spread of RUART was obviously faster, and in a few months a large number of Russian artists had the opportunity to exhibit not only in the best galleries of Milan but also to be regularly present in the best Italian and European art fairs with the RUART brand.

Even if, for budget reasons, ITALIART could not aspire to the fabulous exhibition facilities offered by Russia, the cultural network was still able to participate in popular events such as the Russian Art Week, in Moscow, and other similar ones which, although less prominent, were for networks artists still an excellent platform for comparison and a relevant showcase in beginning to be known on the territory.

The variety and diversity of Italian Art and the way of presenting it, easily gained success and interest not only from the public but also from the Russian artists themselves.

\footnotetext{
1 Ifigeneia M., Dimitrios A. 2018. Globalization, Social Media and Public Relations: A Necessary Relationship for the Future? KnE Social Sciences. [online] Knepublishing.com. URL: https://knepublishing.com/index.php/KnE-Social/article/ view/3546/7438\#info (accessed 01.05.2020).

2 ITALIART http://www.italiart.ru/

RUART http://ruart.su/
} 
In particular they were intrigued and fascinated by that «something new» that the official art critics and the «top» Italian contemporary art world, is less aware. ITALIART was starting to do what is for them the real cultural sharing!

They were beginning to establish a creative link with those who really make the culture of a country. The artists!

The curiosity, the questions, the criticisms, in particular of the artists themselves, became for them a source of inspiration and knowledge and today are the basis of our guidelines to organize and propose new events. The exchange had really begun!

Today, in 2020, the ITALIART and RUART projects work in complete synergy in the name of a real artistic sharing between these two countries representing both Italian and Russian art in a range of key events. They include ARTKULTURA, VOX ANIMAE, MOYA ITALIA (expressly dedicated to Russian artists) and the third exhibition ITALIARTKREMLIN ${ }^{4}$ brings a selection of the best Italian contemporary art in the Vernadsky State Geological Museum in Moscow.

\section{КУЛЬТУРНЫЕ СЕTИ ITALIART И RUART: МЕЖДУНАРОДНОЕ ХУДОЖЕСТВЕННОЕ ПАРТНЕРСТВО}

\section{Э. Ван Холстен, А.А. Королева, А.Н. Никифорова}

Ван Холстен Эмануэль - магистр техники визуальных коммуникаций (DWA, Дюссельдорф, Германия); магистр визуальных искусств и приложений (Кельн, Германия), исполнительный директор и арт-куратор ITALIART ARS NOVA Russia / ItalianDivision. http://www.vanholsten.com. 20131, Милан, П. Удине, 6. E-mail: evh@italiart.ru

Королева Алина Алексеевна - кандидат культурологии, доцент кафедра «Реклама и связи с общественностью» МГИМО МИД России. 119454, Москва, проспект Вернадского, 76; Государственный геологический музей им. В.И. Вернадского РАН. 125009, Москва, Моховая ул., д. 11, стр. 11. E-mail: a.koroleva@inno.mgimo.ru

Никифорова Анастасия Николаевна - бакалавр рекламы и связей с общественностью МГИМО МИД России; магистрантка программы «Подготовка переводчиков для международных организаций» по направлению Педагогическое образование, МГИМО МИД России. 119454, Москва, проспект Вернадского, 76. E-mail: murchiforova@gmail.com

Ван Холстен Э., Королева А.А., Никифорова А.Н. 2020. Культурные сети Italiart и Ruart: международное художественное партнерство. Концепт: философия, религия, культура. Том 4. № 1(13). С. 181-185. https://doi.org/0.24833/2541-8831-2020-1-13-181-185

Статья поступила в редакцию: 26.01.2020. Принята к публикации: 03.03.2020.

Конфликт интересов. Авторы заявляют об отсутствии конфликта интересов.

На современном этапе наиболее распространенной формой международного сотрудничества в сфере культуры становится сетевой формат работы. В первую очередь он привлекает субъектов международного рынка культуры и искусства сокращением издержек и удешевлением стоимости реализации проектов. Как существовавшие раньше организации взяли на вооружение этот формат и преобразовались в сети, так и новые партнерские проекты с самого

4 ITALIARTKREMLIN http://www.italiartkremlin.ru/ 
начала выстраивают свою структуру на принципе горизонтальных коммуникаций. Наряду с представителями государственных структур, международных организаций, существуют сети, инициатором которых являются независимые эксперты, заинтересованные в развитии международного частного партнерства. В 2020 г. в ГГМ РАН пройдет 3-я панорамная выставка современного итальянского искусства «Italiartkremlin». Помимо работ итальянских мастеров, на выставке будут представлены и работы русских художников, победителей ежегодного конкурса «МОЯ ИТАЛИЯ» ИЛИ "ИТАЛИЯ ГЛАЗАМИ РУССКИХ ХУДОЖНИКОВ». «/taliartkremlin» один из проектов культурной сети ITALIART, объединяющей усилия представителей итальянского арт-рынка, а также поклонников и коллекционеров современного итальянского искусства с челью его продвижению в России и странах Европы. Родственная сеть RUART специализируется на популяризации русского искусства в мире и, в особенности, в странах северной Европы, через организацию тематических арт - событий, в том числе художественных выставок, конкурсов, семинаров. Идея соседствования на едином экспозиционном пространстве произведений представителей разных стран мира позволяет сравнивать и увидеть разницу между национальными школами и современными художественными концепциям.

Ключевые слова: культурные сети, межкультурные коммуникации, современное искусство, выставка, итальянское искусство, маркетинг в сфере культуры.

\section{References:}

Brun J., Benito J., Canut P. 2008. Redes culturales. Claves para sobrevivir en la globalización. Madrid: Dirección General de Relaciones Culturales y Científicas de la Agencia Española de Cooperación Internacional para el Desarrollo (In Spanish).

Martínez T.J. 2016. La gestión cutural. Conceptos y experiencias. Madrid: ISPE Publicaciones (In Spanish).

Castells M. 2001. Galaxia Internet. Reflexiones sobre Internet, empresa, sociedad. Madrid: Arête. (In Spanish).

Bosselman M. 2006. Las redes culturales en el ambito internacional. BoletinGc: Gestion cultural 14: Redesculturales. 1697-073X. Julio. (In Spanish).

Koroleva A.A. 2015. Transformatsiya sotsiokul'turnoi identichnosti v usloviyakh perekhoda k setevomu obshchestvu (sravnitel'nyi analiz opyta Rossii $i$ Ispanii) [The Transformation of Sociocultural Identity in the Context of the Transition to a Network Society (a Comparative Analysis of the Experience of Russia and Spain)]: Diss.... kand. kul'turologii. Moscow. 177 p. (In Russian).

\section{Список литературы на русском языке:}

Королева А.А. 2015. Трансформация социокультурной идентичности в условиях перехода к сетевому обществу (сравнительный анализ опыта России и Испании): дисс. ... канд. культурологии. Москва. 177 с. 